Rasim M. Alguliyev ${ }^{1}$, Alovsat G. Aliyev ${ }^{2}$

${ }^{1,2}$ Institute of Information Technology of ANAS, Baku, Azerbaijan

secretary@iit.ab.az, alovsat_qaraca@mail.ru

\title{
GREENING THE ECONOMY AS A NEW STAGE IN THE DEVELOPMENT OF INFORMATION SOCIETY
}

The article analyzes the essence of green economy in the information society and relevant initiatives and appeals in this field. It clarifies principles of green economy are clarified and sheds light on the process of greening as a new stage in the economic development of society. The necessity of transition to formation of green thinking and lifestyle in all spheres of society and economic activity is predicated. The current situation in Azerbaijan regarding the formation of green economy is analyzed and recommendations on the measures of prevention of the harmful aspects are put forward.

Keywords: green economy, green thinking, greening technologies, green economy initiatives.

\section{Introduction}

Although the modernization, innovative development, the increase of competitiveness, and the maintenance of energy efficiency are mainly directed towards economic growth in Azerbaijan against the backdrop of global economic crisis, the primary goal is the improvement of living standards of each individual and the maintenance of decent and sustainable living standards of future generations by the elimination of oil-gas resource dependence, and development of non-oil sector. This issue has been specified as the provision of sustainable development based on the principles of Information Society economy, which is currently under formation. This, in turn, necessitates the world-andcountrywide realization of production and consumption on the basis ecological balancing.

The main program characterizing the environmental protection in overall development of the country - the National Program on ecologically sustainable socio-economic development in Republic of Azerbaijan, was adopted in 2003 [1,2]. As a logical continuation of this program, the "Azerbaijan 2020: the vision of future" development concept [3] adopted in 2012, as well as "The National Strategy on development of Information society in Republic of Azerbaijan in 2014-2020 years" [4], aim at the achievement of ecologically sustainable socio-economic development. During the period covered by the concept, the greening of the economy and utilization of alternative (non-renewable) energy sources will accelerate the processes.

At present, economic growth is accompanied with negative repercussions such as environmental degradation, increase of pollution levels, exhaustion of natural resources, biosphere disturbance and climate changes. This harms human health and impedes the normal development of future generations. In other words, the economy serving to increase the human welfare hinders the improvement of the life standards and does not guarantee the health. Hence, the modernization must be directed toward the progressive innovative technologies, maintaining economic growth in order to protect and improve the productivity and favorableness of natural environment. In such case, ecological security becomes a prominent factor for both economic growth and the better and healthier human existence.

\section{Reasons, Tasks and Principles of Transition to Greening the economy in Information society}

The concept of formation and development of green economy encompasses several directions such as resource-oriented economy, environmental economy, green technologies and etc. The "brown economy", in contrast to green economy, is based on extensive use of resources, low energy efficiency, dependence upon non-sustainable energy sources and high-level climate risk. 
The international organizations such as Organization of Economic Cooperation and Development (OECD) and Environmental Program of United Nations consider "green development" or "green economy" as a process contemplating the production and consumption of goods and services providing ecological security, as well as the investments into green development and technologies [5]. In this view, the factors such as economic development, profitability, employment and poverty reduction are considered in detail, while maintaining environmental sustainability.

The establishment of green economy is mostly regarded as one of the promising directions for escape from the global financial-economic crisis. The concept of green economy is not fully superseded by the sustainable development concept. However, the achievement of sustainability is dependent upon the correct formation of economy. During the past decades, new wealth had been created, based on the brown economy, by the humanity. The greening of the world economy is necessary for the development of sustainable economy. At present, the signs of establishment of new economic model are observed in individual countries. Global economic recession has also necessitated the establishment of green economy. Ecological component already occupies one of the significant places in anti-crisis programs developed by several governments.

At present, there is no a holistic concept, which specifies the coverage of green economy. Individual countries adopt this process in slightly different forms. Actually, the differentiation of appropriate measures taken in economy from country to country is acceptable. Because, great differences, in terms of quality, exist between the human capital of -developed countries and developing or newly industrialized countries, and these differences are also reflected in measures related to green economy of respective countries.

The necessity of transition to green economy is emerged from three main reasons [6]:

1. Enlargement and intensification of human impact on environment within a limited area is impossible. The increase in impact opportunities due to the space and the vast of ocean depths is quite limited in the current state and near future.

2. Non-renewable natural resources on the Earth are not inexhaustible. Growing population and their growing needs pose big problems in terms of their satisfaction of these needs and fair distribution of existing goods.

3. It must be considered that any negative process occurring in any corner of the Earth, as a result of human activity, will have an impact on other areas as well within some time period.

Therefore, it becomes clear that new approaches must be applied for the solution of ecological, social and economic problems faced by the humanity in a modern world. Thus, it can be thought that "green" labor activity, "green" economy, "green" production, "green" thinking and "green" lifestyle must become one of the main components of our future life.

The transition to green economic system encompasses three periods [7]:

$\checkmark$ First period - covers the period until 2020, which include educating population and the development of human capital.

$\checkmark$ Second period - covers 2020-2030 years, which considers the formation of elements of green economic system.

$\checkmark$ Third period - covers 2030-2050 years. The benefits of green economic system are reaped and sustainable development is maintained in this period.

Greening the economy divides the existing problems in the society into four main categories: ecological, intellectual, political and ethical. Favorable conditions and situation must be established for the transition to green economy. National legal-regulatory acts, policies, material aid and incentives, world market, legal infrastructure, goods turnover and financial aid, and etc. are encompassed herein. In the United Nations Environment Program (UNEP) Report titled "Transition methods to green economy, sustainable development and poverty elimination" [5], 10 main sectors of the green economy, where it is necessary to invest in, were specified: agriculture, 
construction, energy supply, fishery, forestry, energy effectiveness, tourism, transport, waste management, water resources management.

\section{Economic Mechanisms and Conditions of the Transition to Green Economy}

Following points can be considered as the mechanisms of transition to establishment and development stage of the green economy:1) evaluation in accordance with sustainable development principles; 2) relevant amendments to taxation system, transition from labor power taxation to pollution taxation by considering ecological principles; 3 ) the government procurement policy considering the production of ecological products; 4) the increase in volume of government investments in ecological infrastructure complying with sustainable development principles; 5) state support to research and development on establishment of ecologically clean technologies; 6) social strategies directed toward the maintenance of compliance among economic strategies.

Moreover, UNEP has prepared recommendations related to transition policy and conditions of transition to green economy. The terms include [8,9]: 1) creation of efficient legal-regulatory principles of transition; 2) the priority of government investments and spendings in sectors stimulating the greening of economic sectors; 3) cost reduction in sectors exhausting natural capital; 4) the application of taxes and other market mechanisms for encouragement of green investments and innovations; 5) investments in development of training and education; 6) strengthening the international cooperation. These terms affirm the necessity of strengthening the role of government during transition to green economy and improvement of government policy once again.

Evidently, the international cooperation and aid have a significant role among the conditions of transition to green economy. Hence, international ecological agreements ease and stimulate the transition to green economy. It can play a prominent role in solution of global ecological problems, of economic activity and in multilateral ecological agreements. The UN convention on climate change can pose a greater impact on the process of transition to green economy than all international ecological agreements [8].

\section{The Process of Greening as a New Stage in Development of Society and Economy}

Number of problems are posed to the ICT and IS, the sectors constituting the basis of knowledge and skills in maintenance of development based on human potential, which is a priority of the $21^{\text {st }}$ century. A prominent direction of modern times is the training of citizens serving to development based on knowledge, science and advanced technologies. Several tendencies observed in various parts of the world have demonstrated that life conservation and the maintenance of long-term development require the formation of new priorities in human economic activity. The most prominent ones of those are green economy, green lifestyle, green thinking, green mind and green intellect that provide sustainable development. The establishment of green economy is the main instrument of provision of long-term development based on available natural resources and knowledge.

The steps, taken by Azerbaijan in this direction, were initiated by ICT strategy approved by the national leader Heydar Aliyev [1]. At present, new tendencies and new appeals have emerged in sustainable and human potential-based development trend. These can be specified as "green economy", "green lifestyle", "green consumption" or "green behavior". The green economy and green production implies the human activity in industry and agriculture, which considers laws of nature, features not negative impact on environment, and utilizes natural resources efficiently and economically [6-12].

At the current stage, "green" knowledge and skills bear a specific importance. Experts trained for the future labor market must respond to these appeals both as professionals and citizens. Sustainable and long-term development, serving to interests of future generations, can only be provided within the framework of expert training based on such principles. 


\section{International Initiatives, Organizations and Practices on Formation of Green Economy}

The UN Environment Program has put forth with initiative on establishment of green economy several times. The "green economy", targeting the formation of the economy of the future, is constructed upon three main principles [8, 10]: 1) evaluation of natural services at national and international levels; 2) employment maintenance of population by creating "green" jobs; 3 ) implication of market mechanisms for provision of sustainable development.

In 2010, "G20" country leaders proclaimed, in the Declaration in Toronto, that evaluation methods considering the social and ecological outcomes of economic development must be applied, from now on, for sustainable and more balanced development [13].

In the UN Conference on sustainable development ("Rio+20"), held at high level in 2012, "The green economy within the context of sustainable development and poverty reduction" was one of the main topics. In this case, the conduction of additional studies has been proposed for the specification of acceleration opportunities of transition process of "green" economy to sustainable development [13]. In the UN Sustainable Development Conference ("Rio+20"), the governments have agreed that the green economy is a main instrument for sustainable development. The "Rio+20" Declaration also mentions the pursuit of the green economic policy with information exchange and realization of potential opportunities.

Around 60 international initiatives have been attempted to be realized on development of green economy thus far. Fourteen of them were attributed to international forums. Main targets of the platform in those forums were specified as information exchange, science and knowledge management, and global climate change.

The following international organizations mainly operate in the field of the green economy [5]: 1) United National Environment Program (UNEP); 2) UN Development Program (UNDP); 3 ) UN Food and Agriculture Organization $(F A O)$; 4) International Union for Conservation of Nature; 5) Worldwide Fund for Nature; 6) Green World Global, etc.

The UN preserves a leading role in solution of biosphere protection-related issues. Besides, some primary institutions and specialized organizations of the UN carry out works related to green economy issues at some degree.

In the "Global ecological perspective - 2000", adopted with the participation of 850 UN experts and more than 30 environmental organizations at the beginning of $21^{\text {st }}$ century, it has been decided that the solution of environmental problems in the new millennia is solely possible with joint efforts [8].

Primary initiators of green economy-related programs being carried out are the active countries such as Norway, Denmark, Australia, Germany, Spain and Sweden along with abovementioned organizations.

While mentioning the practice of separate countries in development of green economy, the implemented reforms and applied mechanisms must be considered. Therefore, each country has its own features. The following versions of mechanisms appropriate for use in development of green economy can be mentioned [14-16]: ecological tax reforms and tools (for instance, carbon tax, tax concessions and cuts); 2) penalties for intensive pollution; 3) green subsidies, grants and credits for financing ecological projects; 4) elimination of subsidy maintenance for ecologically harmful activities; 5) direct government spending (for instance, ecologically clean infrastructure for organization of research and development ( $\&$ \&) for clean technology), indirect support (for example, public guarantees and etc.).

In Great Britain, Feed-In Tariffs Scheme (FITS) concession tax is applied in direction of development of green economy [17]. In Germany, ecological tax (Eco Tax) reform is adopted for the development of green economy [18].

While applying green subsidies as a tool, the factors of external environment (globalization, international competition, internal market conjuncture, consumer psychology and etc.) must be taken into consideration $[19,20]$. 


\section{The Current Situation in Formation of Green Economy in Azerbaijan}

The development of non-oil sector alongside with oil sector, the progress in regions, the integration to the global economic space and the increase in economic competitiveness have shaped an irreversible image. At present, a successful policy is being carried out in direction of green economy establishment as a component of sustainable development of Azerbaijan.

There is a favorable basis for realization of comprehensive environmental policy in the country. In accordance with the decisions of the Rio+20 and Johannesburg Summits, Azerbaijan implements the upgrade of environmental policy and legislation [13]. Some tasks are accomplished in adoption of government programs and laws, application of new administration principles, enhancement of national park networks, improvement of water supply for people, waste management and environmental protection amongst environmental measures.

The following principles of environmental legislation in Azerbaijan contemplate the development of the green economy [21]: 1) mutual solution of socio-economic, moral problems; 2) maintenance of sustainable utilization of natural resources; 3) provision and conservation of environmental balance; 4) ecosystematic approach in regulation of environmental protection and natural resources utilization; 5) sanctions related to environmental pollution; 6) paid use of nature; 7) maintenance of ecological balance in areas and the restoration of disturbed natural ecological systems; 8) efficient utilization and restoration of natural resources, the application of economic encouragement of nature utilization and environmental protection; 9) provision of protection of environmental biovariety; 10) the responsibility for the violation of environmental protection legislation; 11) evaluation of damage incurred to nature; 12) environmentally sustainable socioeconomic development, the protection of human life and health; 13) joint participation of population and public unions in environmental protection; 14) international cooperation in environmental protection, the adaptation of ecological legislative framework to European legislation and international agreements $[22,23]$.

Agriculture is the main source of employment in Azerbaijan and is very important for economic diversification. Agriculture is also valued due to the fact that this sphere has a prominent role in terms of food security and poverty reduction in regions. Azerbaijan has extensive opportunities for the development of ecologically clean farming, and expansion of export of the products to the world and to European market in particular. The government of Azerbaijan supports the agriculture with subsidies, leasing services, concessional credits and tax policy and carries out large-scale melioration and irrigation measures.

As seen from SWOT analysis in Table 1, Azerbaijan has a strong potential for development of green economy [24]. However, existing weak sides and threats impede the development of green economy. At present, system-generating paradigm of green economy - human capital development constitutes the basis of economic policy in Azerbaijan. The conduction of complex programs carried out within this policy framework (fighting poverty, sustainable development, socio-economic development of regions, food and energy security, education, information and communication technologies and etc. spheres) will maintain the achievement of targeted goals.

The evaluation of each concept according to different criteria reveals negative and positive aspects [25]. From this point of view, the green economy is no exception. It is because the measures and programs of transition to green system can harm one country, but benefit another. An accurate assessment must be carried out before the realization of incentives, and opportunities must be created for rapid adaptation of people to innovations. Negative impacts of transition to green economy can occur in developing countries and resource-rich countries. 
Table 1.

SWOT analysis (strengths and weaknesses, opportunities and threats) of the greening the

Azerbaijani economy

\begin{tabular}{|l|l|l|l|}
\hline \multicolumn{1}{|c|}{ Strengths (S) } & \multicolumn{1}{|c|}{ Weaknesses (W) } & \multicolumn{1}{c|}{ Opportunities (O) } & \multicolumn{1}{c|}{ Threats (T) } \\
\hline $\begin{array}{l}\text { Government interest for } \\
\text { green development }\end{array}$ & $\begin{array}{l}\text { Lack of business } \\
\text { interest for green } \\
\text { economy }\end{array}$ & $\begin{array}{l}\text { Dynamic price policy } \\
\text { for energy inputs }\end{array}$ & $\begin{array}{l}\text { Increase in } \\
\text { bureaucratic obstacles }\end{array}$ \\
\hline $\begin{array}{l}\text { Import concessions for } \\
\text { several green } \\
\text { technology equipment }\end{array}$ & $\begin{array}{l}\text { Substantial financial } \\
\text { investment resources } \\
\text { requirements }\end{array}$ & $\begin{array}{l}\text { The opportunity of } \\
\text { directing additional } \\
\text { resources towards } \\
\text { green development }\end{array}$ & $\begin{array}{l}\text { Inaccurate application } \\
\text { of legislative } \\
\text { framework }\end{array}$ \\
\hline $\begin{array}{l}\text { Increasing interest of } \\
\text { experts for green } \\
\text { economy }\end{array}$ & $\begin{array}{l}\text { Inability of population } \\
\text { to fully evaluate the } \\
\text { importance of the } \\
\text { problem }\end{array}$ & $\begin{array}{l}\text { Establishment special } \\
\text { green business zone }\end{array}$ & $\begin{array}{l}\text { Clash of different } \\
\text { economic interests }\end{array}$ \\
\hline $\begin{array}{l}\text { The willingness of } \\
\text { institutional } \\
\text { organizations to } \\
\text { establish favorable } \\
\text { environment and } \\
\text { mechanisms }\end{array}$ & $\begin{array}{l}\text { Lack of specification } \\
\text { of green tariff }\end{array}$ & $\begin{array}{l}\text { The necessity of } \\
\text { upgrading } \\
\text { technological basis of } \\
\text { economy }\end{array}$ & $\begin{array}{l}\text { The weakness of } \\
\text { management }\end{array}$ \\
\hline $\begin{array}{l}\text { The sensitivity of } \\
\text { population toward } \\
\text { ecologically clean } \\
\text { products and } \\
\text { environment }\end{array}$ & $\begin{array}{l}\text { Lack of professionals } \\
\text { in the field of green } \\
\text { technologies }\end{array}$ & $\begin{array}{l}\text { The expansion of } \\
\text { application of tax and } \\
\text { customs concessions }\end{array}$ & $\begin{array}{l}\text { The decrease in } \\
\text { corporate social } \\
\text { responsibility }\end{array}$ \\
\hline $\begin{array}{l}\text { The sense of } \\
\text { environmental } \\
\text { protection of population }\end{array}$ & $\begin{array}{l}\text { Weak cooperation of } \\
\text { government and } \\
\text { business sector }\end{array}$ & $\begin{array}{l}\text { The establishment of } \\
\text { special economic } \\
\text { zones and industrial } \\
\text { clusters in } \\
\text { corresponding area }\end{array}$ & $\begin{array}{l}\text { Some degree of } \\
\text { negligence and } \\
\text { ignorance by } \\
\text { population }\end{array}$ \\
\hline
\end{tabular}

The mistakes, made in earlier periods of transition to green economy, can reduce the efficiency of the system in following periods. in this regard, developing countries are worried to a greater extent. It is because, the population of developed countries is advanced in human development index, especially in an education level. As a result, in case if developing countries can accomplish the first stage successfully and shift to the second stage, developing countries may face a failure due to the lack of human capital in the first period. That is why, some developing countries consider the transition to green economy as a new political game organized by developed countries. Hence, developing countries, especially the countries rich with natural resources such as oil and gas, must be approached carefully. For successful completion of the transition period, also in developing countries, the support of developed countries is required. This aid can be expressed as following [25]:

$\checkmark$ Enlightenment and organizing trainings, courses and conferences for adaptation to reforms;

$\checkmark$ The providing developing countries with one of the most valuable resources information by enhancing cooperation between the state and private sector;

$\checkmark$ Mass media support in promotion of green economy;

$\checkmark$ Assistance for the systematic solution of water scarcity problem in developing countries;

$\checkmark$ Investing in agriculture as a potential field of the green economy; 
$\checkmark$ Installment of the Foreign Direct Investments in development of alternative energy sources in countries rich with renewable natural resources;

$\checkmark$ Transfer of successful and respective practice in green economy field to relevant countries;

$\checkmark$ Consideration of economic situation of developing countries in initiative endeavors and etc.

In general, the transition to green economy does not contemplate that all other problems are already solved. Several problems exist, the solution of which is only possible on the basis of complex approach.

\section{Conclusion}

In recent years, less energy utilization and its generation from cleaner sources have been specified as a common target in curbing global economic crisis and climate changes at international level. This is also the crucial condition for another issue such as transition to sustainable development and environmental civilization.

E-government technologies, ICT and information society are encountered with number of problems in securing human potential-based development as a main priority of the $21^{\text {st }}$ century. The training of highly specialized experts is a primary concern of a society based on knowledge, science and advanced technologies in a modern world.

The World Summit dedicated to global climate change and ecological and economic problems related to these processes has demonstrated that the provision of long-term development of the Earth planet necessitates the formation of new priorities in human economic activity and lifestyle. The most important of those are "green" economy, "green" lifestyle and "green" thinking, "green mentality" and "green intellect", which counteract with environment and maintain sustainable development. The economy and society of Azerbaijan must succeed the development of non-oil sector by using the greening technologies of post-industrial economy in a most efficient way, and information society, in turn, must achieve the greening of economy by tracking and applying the most advanced technologies.

Despite some negative features of the green economy, its advantages overweigh the drawbacks. Hence, the green economy must be considered as an a sole way to sustainable development.

\section{References}

1. National Program on ecologically sustainable socio-economic development in Republic of Azerbaijan, 18 February 2003, http://www.eco.gov.az

2. State Program on utilization of alternative and renewable energy sources in Republic of Azerbaijan, 21 October 2004, http://www.eco.gov.az

3. "Azerbaijan - 2020: the vision of future" Development Concept, 29 December 2012, http://www.president.az.

4. National Strategy on Development of Information Society in Republic of Azerbaijan for 20142020 years", 2 April 2014, http://www.president.az.

5. www.oecd.org, http://www.unep.org, www.fao.org/home/en

6. Alekberov U. "Green" economy and vocational training: a new stage of civilization a pathway to environmental civilization (ecocivilization), http://www.muallim.edu.az

7. Gasimli V., Valiyev Z., Humbatov M. and co. Green Development: energy efficiency and alternative sources. The Center for Strategical Studies under President of Republic of Azerbaijan, 2014, 144 pp.

8. United Nations Environmental Programme: Green Economy, http://www.unep.org/greeneconomy

9. Towards a Green Economy. Pathways to Sustainable Development and Poverty Eradication. United Nations Environmental Programme, 2011. 
10. Global "green" new deal. UNEP Report, 2009, http://www.unep.org/greeneconomv/portals/30/docs/GGND-polisv-brief

11. Medyanik N.V. The formation of spatial paradigm of green economy // Economy and society, 2014, №2-3 (11), pp. 396-399.

12. Porfiryev B.N. "Green" economy: new trends and directions of world economic development // Scientific works: Institute of national economic forecasting RAS, 2012, vol. 10, pp. 9-33.

13. http://www.uncsd2012.org

14. Yang P. Black energy intensity versus green energy intensity: implications for sustainable development // International Journal of Green Economics, 2014, vol. 8, issue 2, pap. 93-119.

15. Musina L.A., Kvasha T.K. A study of the effect of resource efficiency on the economic development in countries that are leaders of "green" modernization // Economy problems (Kharkov), 2014, № 4, pp. 53-61.

16. Dinda S. A theoretical basis for green growth // International Journal of Green Economics, 2014, vol. 8, issue 2, pp. 177-189.

17. http://www.energysavingtrust.org.uk/domestic/feed-tariff-scheme

18. http://www.eco-tax.com

19. Shekhurdina V.I. Green economy - competitive advantage of XXI century state // Economics and management of administrative systems, 2014, vol. 1, № 1 (11), pp. 086-092.

20. Bochko V.S., Nekrasov A.A. Green economy: the theory of matter // The Journal of Economic Theory, 2014, №1, pp. 244-248.

21. "The Law on Environmental Protection of Republic of Azerbaijan", $8^{\text {th }}$ June, 1999, http://www.eco.gov.az

22. Bruyère S., Filiberto D. The green economy and job creation: inclusion of people with disabilities in the USA // International Journal of Green Economics, 2013, vol. 7, no.3, pp. 257-275.

23. Lin J. Study on Green Economy Transformation in Developing Countries / Proceedings of the 2nd International Conference on Green Communications and Networks, 2012, vol. 5 pp. 315323.

24. Makower J., Pike C. Strategies for the green economy: opportunities and challenges in the new world of business, New York: McGraw-Hill, 2009, 290 p.

25. T.G., Okereke C., Environmental justice and conceptions of the green economy // International Environmental Agreements: Politics, Law and Economics, 2015, vol. 15, issue 1, pp. 13-27. 